\title{
THE WANDEL SEA BASIN FROM HOLM LAND TO LOCKWOOD $\varnothing$, EASTERN NORTH GREENLAND
}

\author{
Eckart Håkansson, Claus Heinberg and Lars Stemmerik
}

The field work in the Wandel Sea Basin in 1980 (fig. 17) concluded the geological study initiated in 1976 (Håkansson \& Heinberg, 1977; Håkansson, 1979). During the field seasons large collections of fossils and sediments were made throughout the Early Carboniferous to Paleocene sequence (fig. 18). Investigation of this material is at a preliminary stage, and detailed biostratigraphic correlations and lateral facies relations have yet to be established for most intervals. The present report summarises the observations made in 1980 and gives preliminary results.

Wandel Sea Basin sediments are up to $7 \mathrm{~km}$ thick in total. Thus, they exceed the comparable Svalbard succession (Worsley \& Mørk, 1980). The Wandel Sea Basin development parallels to a great extent that in Svalbard, particularly during the Carboniferous to Triassic periods (Håkansson et al., 1981), but there are pronounced differences between these two regions around the Cretaceous-Tertiary boundary (fig. 18). In contrast to the situation in Svalbard and most of the North Atlantic region there is evidence in North Greenland of a significant orogenic pulse close to the Cretaceous-Tertiary boundary. Furthermore, in the Wandel Sea Basin, considerable thicknesses of Late Cretaceous marine and non-marine sediments are preserved.

\section{Basement of the Wandel Sea Basin}

The Wandel Sea Basin sediments rest on a great variety of rock types. In eastern Peary Land they rest, mainly, on the Early Palaeozoic non-metamorphic rocks of the North Greenland fold belt and its hinterland (Håkansson, 1979) and finds of isolated outliers of Wandel Sea Basin sediments deep inside the fold belt (Soper, Higgins \& Friderichsen, 1980; and below) have extended the known area of the basin.

In Kronprins Christian Land, a great deal of confusion has arisen from previous superficial interpretation of aerial photographs and reconnaissance flight observations.

In Holm Land the basement is composed of red, isoclinally folded, biotite gneiss with a marked regional trend and axial planes striking approximately NE-SW (see also Jepsen \& Kalsbeek, this report). These gneisses are known as far north as Wegener Øer in Ingolf Fjord.

Basement rocks are poorly exposed in most of Amdrup Land. A minute outcrop of possible Proterozoic sandstones of the Independence Fjord Group was located just south of Hjørnegletcher. In the northern part of Amdrup Land extensive series of high grade metamorphic rocks make up several, well differentiated, units of light mica schist, red biotite (augen-) gneisses, quartzites (in places with a strong fuchsite stain), and amphibolites. The mica schists, in particular, have preserved ghosts of sedimentary structures. This basement complex should probably be regarded as a suite of metasediments and metadolerites. The age and lateral continuation of the suite are not known, but judged by external characters alone the biotite gneiss could well be comparable to the biotite gneisses on Holm Land. 


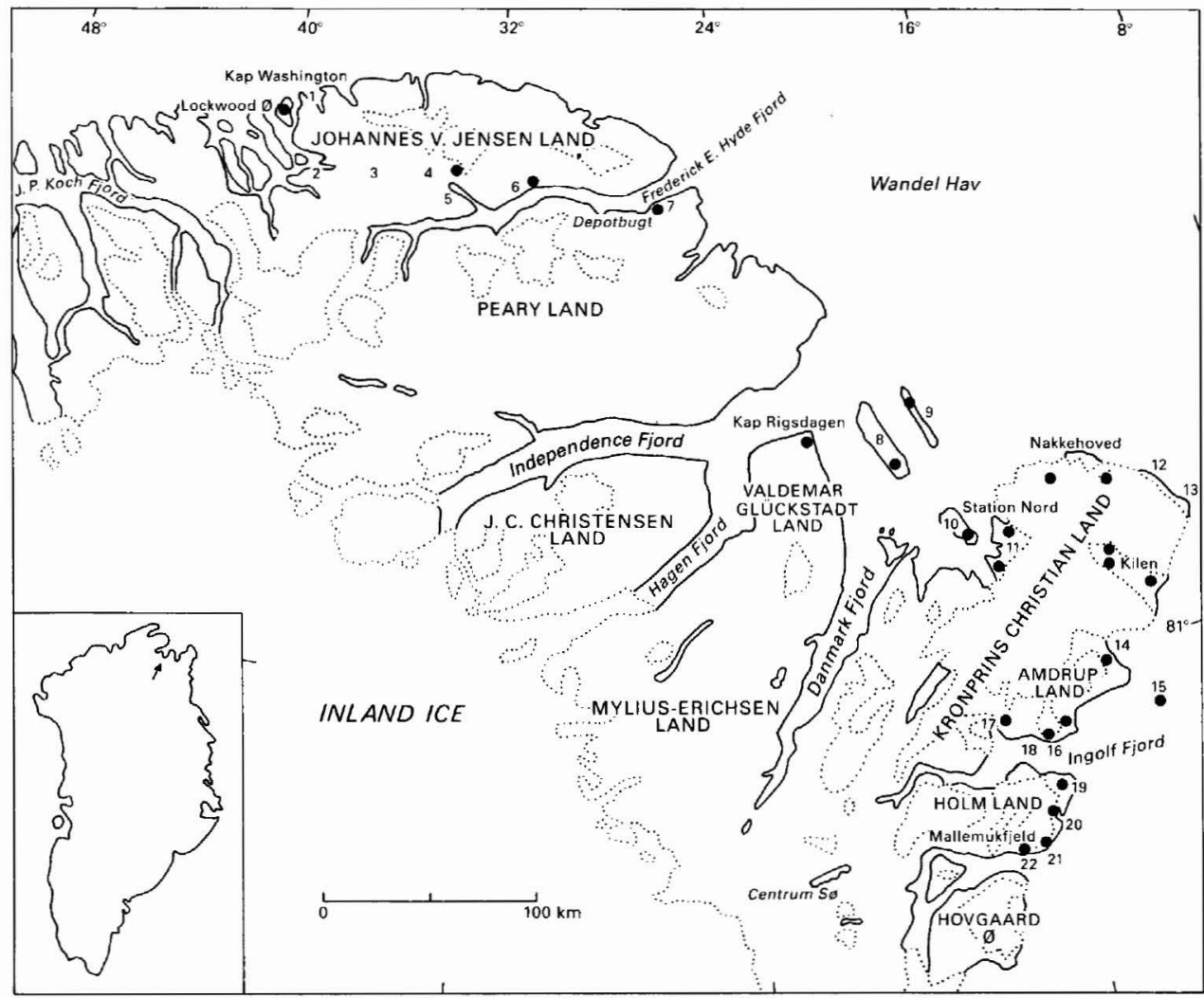

Fig. 17. Toponymic map of the Wandel Sea Basin region, eastern North Greenland. Camps and major groundstops in 1980 indicated by solid black dots. Place names: 1 . Kap Kane; 2. Harder Fjord; 3. Columbus Sø; 4. Grønnemarken; 5. Frigg Fjord; 6. Midtkap; 7. Hundeskrænten; 8. Prinsesse Thyra Ø; 9. Prinsesse Margrethe Ø; 10. Prinsesse Dagmar $\emptyset ; 11$. Prinsesse Ingeborg Halvø; 12. Erik S. Henius Land; 13. Nordostrundingen; 14. Antarctic Bugt; 15. Henrik Krøyer Holme; 16. Kap Jungersen; 17. Hjørnegletscher; 18. Wegener Øer; 19. Mågefjeld; 20. Hansêraq Fjord; 21. Depotfjeld; 22. Sortebakker.

In Kilen no pre-Wandel Sea Basin rocks are exposed; there are only strongly disturbed Late Jurassic and Cretaceous sediments (see below).

In the poorly exposed northern part of Prinsesse Ingeborg Halvø (i.e. east of Station Nord) neither the distribution of, nor the detailed relation between, the Wandel Sea Basin and its basement have been fully clarified. Double folded, low grade, metamorphic basement rocks appear to be closely associated with single folded but similarly metamorphosed Permo-Carboniferous strata (see below). Among the basement rocks, various greenstones and sediments have been noted. Sediments referable to the Rivieradal sandstones or to the basal clastic unit of the Campanuladal Formation, and to the Fyns Sø Formation have been identified (J. M. Hurst, personal communication). Also turbidite sequences with well preserved trace fossils (e.g. Phycosiphon) could be of Silurian age.

The $F_{1}$ phase in the double folded system was undoubtedly identical to the main East Greenland Caledonian episode which led to extensive formation of nappes in Kronprins 
Christian Land (Hurst \& McKerrow, this report). As discussed later the $F_{2}$ phase probably took place some time around the Cretaceous-Tertiary boundary. Also the $F_{2}$ episode probably led to the weak secondary deformation further to the south, in Kronprins Christian Land, noted by J. M. Hurst (personal communication).

\section{Late Palaeozoic strata}

\section{Southern Holm Land: Continental Early Carboniferous}

Continental Early Carboniferous rocks (Nathorst, 1911) are confined to Sortebakker in the southern part of Holm Land where more than $600 \mathrm{~m}$ of rythmically deposited shales and sandstones are preserved. They contain a moderately preserved flora (predominantly as coalified trunks and trunk impressions). Only locally do notable amounts of coal occur.

The relation to the underlying basement is obscure, and conglomerates were observed only somewhat higher in the sequence. Lateral facies variation is substantial, but with little apparent regional trend. The depositional environment was fluvial with abundant sheet flood sands and a few channel sands. The age of the flora was determined by Nathorst (1911) as Early Carboniferous, and subsequently Koch (1929) referred the sequence to his Mt. Pictet Formation. However, the type area for the Mt. Pictet Formation lies more than $600 \mathrm{~km}$ to the south and bears little resemblance to the sequence in Holm Land. Therefore, this name is not maintained in relation to the continental Early Carboniferous sequence of the Wandel Sea Basin.

The continental sequence of Sortebakker contains at least two internal, low angle unconformities and has been subjected to some disturbance along a number of $\mathrm{N}-\mathrm{S}$ striking faults prior to the Late Carboniferous transgression of the Mallemuk Mountain Group.

\section{Mallemuk Mountain Group}

Rocks of the Mallemuk Mountain Group (Håkansson, 1979) were examined in three separate areas. Detailed work was concentrated in the type area (Grønwall, 1916; Koch, 1929; Nielsen, in Frebold, 1950; Dunbar et al., 1962), while the Late Palaeozoic marine sequences in northern Prinsesse Ingeborg Halvø and Lockwood $\varnothing$ were briefly visited.

\section{Holm Land and Amdrup Land}

On Holm Land and Amdrup Land the Mallemuk Mountain Group comprises more than $1100 \mathrm{~m}$ of shallow marine carbonates, sandstones, and shales with local gypsum (fig. 19). The sequence overlies the continental Early Carboniferous with an angular unconformity at southern Holm Land, while further to the north Precambrian (?) gneisses constitute the transgressed basement. Subdivision into a number of facies associations (informal sedimentary units) is proposed. However, it is premature to attempt a correlation with the formal subdivisions of the Mallemuk Mountain Group in eastern Peary Land (Håkansson, 1979).

Facies association a consists predominantly of dark grey limestone interbedded with recessive, red and green sandstones and minor conglomerates. In southern Holm Land the sequence overlies the continental beds with at the base a red conglomerate approximately

4 Rapport nr. 106 


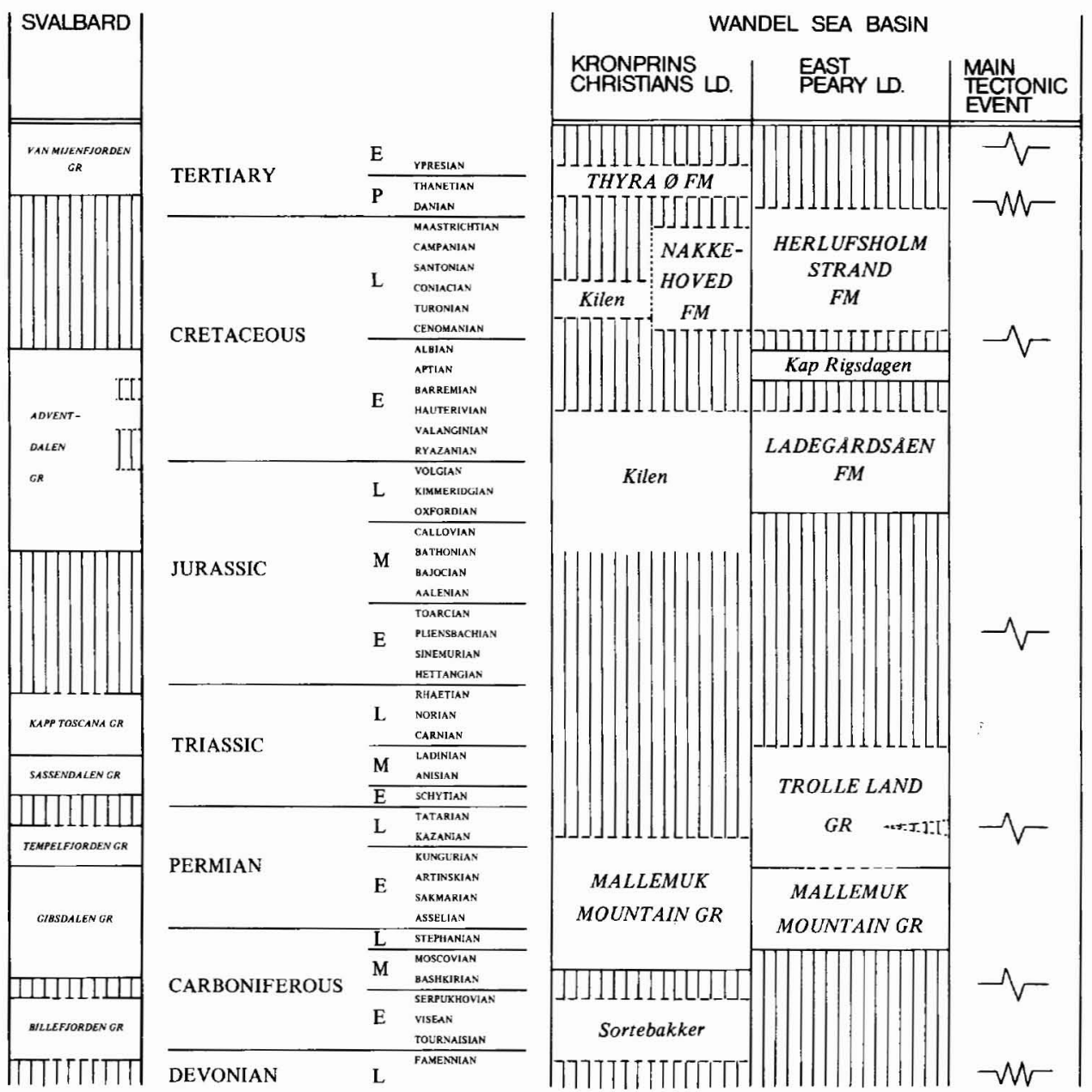

Fig. 18. Stratigraphy of the Wandel Sea Basin compared to Svalbard. (Note - outliers from the Harder Fjord fault zone and the Kap Cannon thrust zone are not included).

$10 \mathrm{~m}$ thick composed almost exclusively of crystalline and other distantly derived clasts. Alternating limestone and sandstone beds, which reach a total thickness of approximately $575 \mathrm{~m}$, form the rest of the cliffs of Depotfjeld and the lower part of Mallemukfjeld.

Towards the north on Holm Land the unit thins out rapidly, and at Hanseraq Fjord it is only about $180 \mathrm{~m}$ thick and rests directly on the Precambrian(?) basement.

The limestone beds contain a sparse fauna of chaetetids, rugose corals, and crinoids as well as rare fusulinids. Colonies of chaetetids are often preserved in life position, in places forming low 'patch reefs' which cover several square metres. Towards the top of the sequence the fossils are commonly impregnated with red and orange chert. On the other hand, the medium grained sandstone beds contain no fauna and are composed mainly of trough cross-bedded and parallel laminated units. A shallow marine environment is envisaged in which quiet periods, indicated by limestone depostion, alternated with higher energy periods which are marked by increased clastic influx. 
On Amdrup Land, approximately $60 \mathrm{~m}$ of similarly interbedded limestone and finegrained, variegated sandstone, plus notable amounts of green shale, constitute the lower part of the Mallemuk Mountain Group. Here the base of the sequence is unknown.

Facies association $b$ is known only in Amdrup Land where it comprises around $200 \mathrm{~m}$ of poorly exposed dark grey limestone. In the lower part, the limestone is finely bedded and highly fossiliferous with a fauna dominated by crinoids and fusulinids but including bryozoans and brachiopods.

Towards the top the limestone is more homogeneous and almost barren of fossils. Here nodules and layers of grey chert are frequently developed.

Facies association c is known only in Amdrup Land where it is particularly well exposed in the cliffs of Kap Jungersen. Here it reaches a thickness of approximately $300 \mathrm{~m}$.

The basal third of the facies association displays complex lateral interfingering of grey limestone, black shale and gypsum. Immediately to the west of Kap Jungersen, three small carbonate mounds are developed in a $50 \mathrm{~m}$ thick gypsiferous sequence. The largest of these mounds is about $20 \mathrm{~m}$ high and contains a very rich and well preserved fauna of barchiopods, bivalves, crinoids, and nautiloids. The remaining part of the unit is dominated by red, medium-grained sandstone with minor intervals of almost unfossiliferous limestone and gypsum.

Facies association $d$ comprises some $300 \mathrm{~m}$ of finely bedded, almost unfossiliferous, grey limestone. Fusulinids are sparse throughout the sequence, while macrofossils are very rare. On Amdrup Land an isolated bioherm(?) was found in the basal part of this sequence containing a sparse fauna of rugose corals.

Facies association $e$ is known from the area around Kap Jungersen where it constitutes a distinct marker bed. However, good exposures are accessible only from the coast (Nielsen, in Frebold 1950, and unpublished data).

The unit comprises approximately $110 \mathrm{~m}$ of interbedded red sandstone and grey limestone. The limestones are generally sandy and contain abundant brachiopods. In the lower part stromatolites frequently occur.

Facies association $f$ comprises more than $200 \mathrm{~m}$ of finely bedded, fossiliferous limestone which terminates the sequence in Amdrup Land. The lower part of the unit is predominantly micritic with scattered brachiopods and corals, but coquina beds, up to one metre thick, also occur. These beds are dominated by brachiopods together with some corals and bryozoans. Red chert nodules occur throughout.

The upper part is composed of richly fossiliferous limestone dominated by brachiopods and bryozoans, with corals and bivalves, as well as a single nautiloid species. Fusulinids are absent. The sequence is divisible into at least twenty assemblages each containing a characteristic fauna. Diversity in individual assemblages varies greatly.

Facies association g, confined to northern Amdrup Land and Henrik Krøyer Holme, comprises some $400 \mathrm{~m}$ of monotonous grey limestone directly overlying crystalline Precambrian(?) basement. At the very base, scattered, local basement pebbles occur in the limestone. In general the limestone is micritic, with little apparent bedding. Fossils occur throughout, with a patchy distribution and confined mainly to boundstone mounds. The fauna includes brachiopods, bivalves, crinoids and nautiloids as well as less abundant corals, trilobites and bryozoans. No fusulinids were found. 


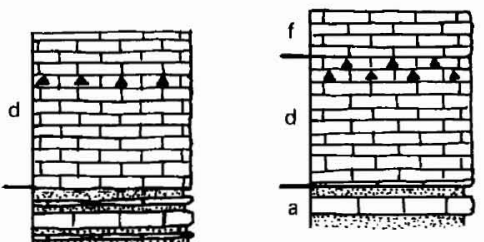

d

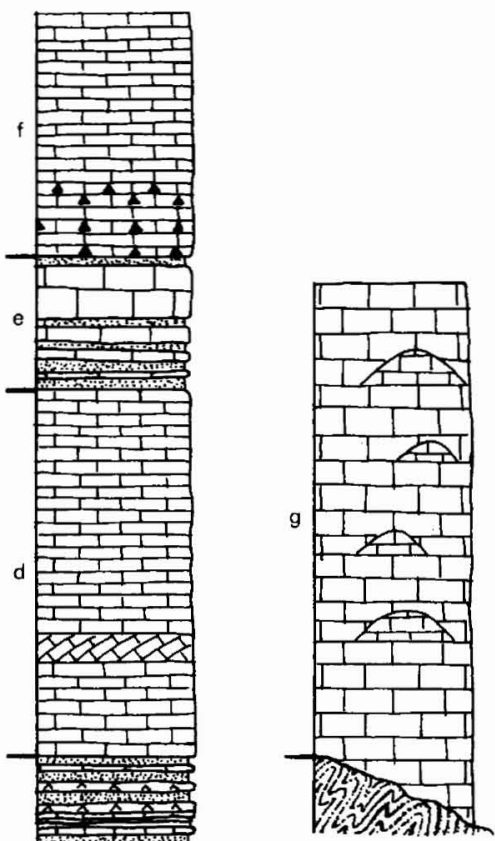

a

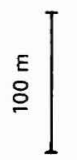

b

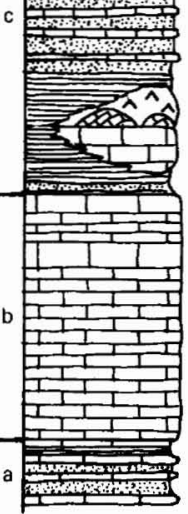

Hansêraq Fjord

Măgefjeld

Kap Jungersen

Antarctic Bugt Mallemukfjeld

Fig. 19. Lithological profiles from the Mallemuk Mountain Group in Holm Land and Amdrup Land. Letters $a-g$ indicate facies association. Solid triangles indicate chert, inverted Vs gypsum. 


\section{Stratigraphy}

On Holm Land and Amdrup Land, the Mallemuk Mountain Group includes sediments of Late Carboniferous to at least late Early Permian (Kungurian) age (fig. 18).

The lower part of the sequence (fig. 19), i.e. the main part of facies association $a$ in the Depotfjeld-Mallemukfjeld section and facies association $a, b$, and parts of $c$ in the Kap Jungersen section, have been dated by means of fusulinids by Dunbar et al. (1962) and includes the Profusulinella and Wedekindellina Zones of the Moscovian Stage. Fusulinids of Stephanian age have, so far, not been recognised on Holm Land and Amdrup Land, but more than $100 \mathrm{~m}$ of undated sediments are present between the level of the uppermost sample containing Moscovian fusulinids, and the lowermost sample, with species of Pseudoswagerina, Pseudofusulina and Swagerina (Dunbar et al., 1962). This fauna is found in approximately $100 \mathrm{~m}$ of sediment in facies association $d$ in the Kap Jungersen and Mågefjeld sections in addition to isolated occurrences from facies association $g$ (fig. 19). It is regarded as belonging to the Asselian and early Sakmarian Stages in accordance with the stratigraphic scheme developed by Douglass (1977). In the Permo-Carboniferous sequence of Spitsbergen, comparable faunas have been referred to the Stephanian Stage (Cutbill \& Challinor, 1965).

Facies associations $e$ and $f$ contain rich faunas of brachiopods, which include a number of species in common with the Tempelfjorden Group in Spitsbergen which Flood et al. (1971) refer to the Kungurian and later Permian Stages. This age assignment is supported by BendixAlmgren (1975) on the basis of sparse occurrences of fish teeth. However, so far no definite Late Permian faunal elements have been identified from the Mallemuk Mountain Group in the Holm Land - Amdrup Land area.

\section{Prinsesse Ingeborg Halvø}

In the northern half of Prinsesse Ingeborg Halvø folded and slightly metamorphosed Late Palaeozoic rocks occur in which two types of limestone seem to dominate: one is fairly homogeneous with a scattered fauna including fusulinids, fenestrate bryozoans, and colonial corals, while the other type is richly fossiliferous, and contains a very diverse fauna of probable Early Permian age (Dawes, 1976). Locally, low grade metamorphic rocks containing Late Palaeozoic faunas have been found. However, owing to poor exposure, little is known about the lateral continuation of these rocks.

Gypsum is present in at least two areas, but nowhere in primary position. Most of the gypsum has been concentrated in the wide fault zone which separates the Palaeozoic and older strata in northern Prinsesse Ingeborg Halvø from the Paleocene Thyra Ø Formation to the south. The fault zone may be $1 \mathrm{~km}$ wide and contains a breccia dominated by black siltstone and cataclastic rocks in a gypsiferous matrix. Individual blocks may take up entire cliff faces and exceed $50 \mathrm{~m}$ in size. Locally, both the gypsiferous matrix and the cataclastic rocks contain significant amounts of hematite. The majority of the clasts in the breccia may, possibly, be related to the low grade metamorphic strata in northern Prinsesse Ingeborg Halvø. On the other hand, in eastern North Greenland primary gypsum is known only in the Late Carboniferous of Amdrup Land (facies association $c$ ) so, most likely, comparable beds are present in the sub-surface of Prinsesse Ingeborg Halvø. 


\section{Mesozoic strata}

\section{Kilen: Marine Late Jurassic and Cretaceous}

The investigation of the Mesozoic strata in the semi-nunatak Kilen in Kronprins Christian Land may represent the most interesting aspect of the 1980 field work. The inner, mountainous part of Kilen had never previously been visited. Previous geological maps of the region have offered a broad variety of opinions concerning this area including 'Permian', 'Proterozoic basement' with an incomplete cover of 'Wandel Sea Basin', or even 'mainly gneisses'. The most apparent reason for this confusion lies in the complex structural patterns discernible from aerial photographs. These structures include major faults, abundant minor faults and distinct domal folding which indicate a degree of deformation not usually associated with late Phanerozoic strata in Greenland.

Our investigation, including a visit to the coastal areas where Greenarctic Consortium (in Dawes, 1976) reported various bivalves as well as an ammonite indicating Bathonian strata, failed to reveal faunas older than Kimmeridgian.

Structurally and statigraphically the sediments of Kilen may be regarded as two distinct entities, separated by a major fault trending approximately $\mathrm{E}-\mathrm{W}$. The northern fault block comprises strata of Late Cretaceous age, while the southern block is composed of Late Jurassic to Early Cretaceous strata. In places a thin Quaternary cover is present, mainly as beach ridges.

\section{Late Jurassic to Early Cretaceous}

The exposed sedimentary sequence is estimated to be about $900 \mathrm{~m}$ thick (fig. 20). The lower $250 \mathrm{~m}$ were logged in some detail, the following $250 \mathrm{~m}$ were recorded more qualitatively wheras the remaining $400 \mathrm{~m}$ were logged at intervals and the total thickness estimated from aerial photographs. The sediments are exclusively clastics, ranging from shaly mudstones to homogeneous coarse sandstones and gravel beds. Fossils occur in places, and trace fossils are fairly abundant at most levels. Organic walled microfossils have been destroyed thermally in most areas. Only in the easternmost part has a poorly preserved palynomorph assemblage been found.

Seven lithofacies have been distinguished (fig. 20), some of which form excellent markers.

Facies a comprises well bedded, dark, very fine-grained sandstone with a high content of organic detritus. The bed thickness is $2-10 \mathrm{~cm}$ at the top and increases downwards.

The individual beds are separated by thin coaly partings which contain abundant plant remains and scattered ammonites. The trace fossils Rhizocorallium (two types) and Thallassinoides (large forms) occur throughout.

Facies $b$ is dominated by poorly exposed, black, shaly, very fine-grained sandstone to siltstone.

Facies $c$ is composed of medium-grained sandstones with minor intercalations of silty shales and very fine-grained sandy layers. The individual sandstone beds are separated by thin silty layers.

The top $5 \mathrm{~m}$ is coarse sandstone to gravelstone with abundant Stenocraterion ('pipe rock'). Thallasinoides occurs throughout the entire unit, and in places predominates on bedding planes. 
(A)

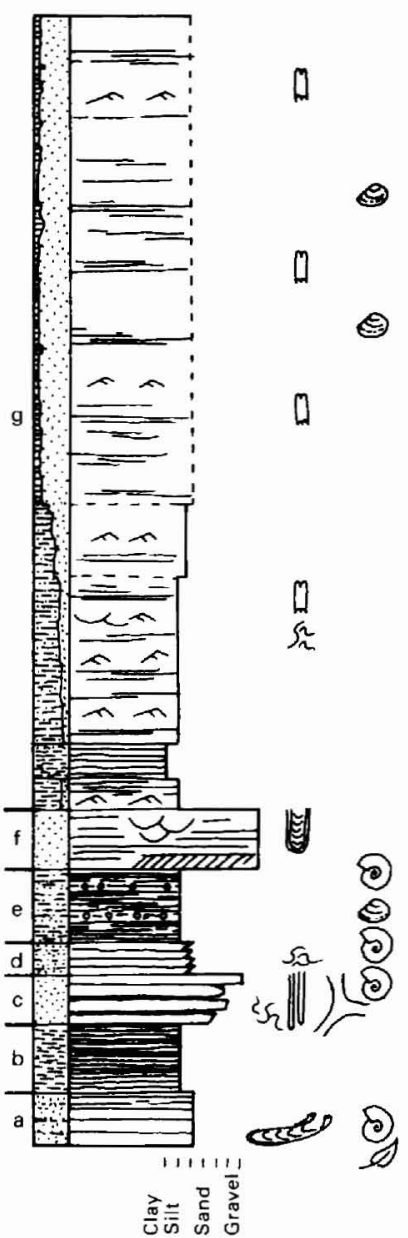

Late Jurassic -

Early Cretaceous

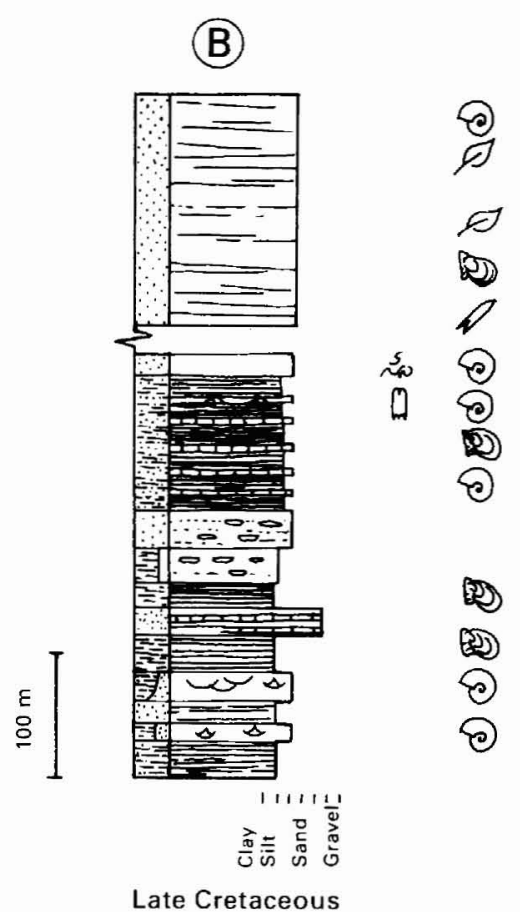

Late Cretaceous

Fig. 20. Composite lithological logs of the Late Jurassic - Cretaceous sequences at Kilen. Main fossil and trace fossil levels indicated. A: Southern part of Kilen, a-e indicate facies. B: Northern part of Kilen.

Facies $d$ is a well bedded, dark sandstone with silty intervals. At the base, the individual beds tend to coarsen upwards from a silty shale to a comparatively pure fine sandstone. Towards the top of the unit, however, the sandstones become cleaner without the silt fraction.

Trace fossils are abundant throughout the unit. Small, black coated, meandering trails are particularly common. Also a very characteristic, small Teichichnus burrow repeatedly occurs. A few, fairly large ammonites were collected from this part of the sequence.

Facies e comprises black, rather uniform silty shale with abundant concretions of two types. Perfect spheres (often black) from one to ten centimetres across are irregularly distributed and conspicuously red, ferruginous concretions form more or less continuous layers which may contain Buchia coquinas, Zoophycos burrows or scattered ammonites. 
Facies $f$ comprises a series of yellow, coarse sandstones and gravelstones with isolated quartzite clasts reaching $20 \mathrm{~cm}$ in diameter. The upper boundary is very sharp and commonly constitutes a distinct marker. Ripple and parallel lamination occur, as well as large scale trough and planar cross-bedding. The latter has sets up to $1.5 \mathrm{~m}$ in thickness.

A single horizon in the middle of the unit is heavily burrowed by large Diplocraterion.

Facies $g$ comprises some $600 \mathrm{~m}$ of frequently interbedded siltstones and sandstones, which terminate the exposed part of the Early Cretaceous sequence. The lower part is dominated by silty and sandy black shales, which occur in intervals tens of metres thick. The majority of the sequence is composed of distinct, thin sandy and shaly layers with an increasing sand/shale ratio upwards. The sandstone beds, ranging from a few centimetres to half a metre in thickness, are of considerable lateral extent and may be traced over hundreds of metres or even kilometres. Parallel lamination, ripple lamination and flat, trough crossbedding occur regularly, and loading was frequently noted.

Trace fossils are common. In the shaly parts, black-coated, meandering trails dominate, while in the upper, more sandy parts a variety of well preserved types occur including Gyrochorte, Phycodes and Pelecypodichnus. Imprints and shells of heterodont and protobranch bivalves occur at certain levels.

The highly sporadic macrofauna collected from this sequence at Kilen has so far yielded ages from the Kimmeridgian (facies $a$ ), the Volgian (facies $d$ ), and the Valanginian (facies $e$ ) (T. Birkelund, personal communication). An isolated, poorly preserved dinoflagellate assemblage from shales of facies $g$ indicates a Valanginian or younger Early Cretaceous age (S. Piasecki, personal communication).

The entire Late Jurassic - Early Cretaceous sequence is interpreted as two separate depositional regimes - a transgressive phase in a muddy, barred, coastal environment, followed by an exposed, open marine, sandy environment. In the former complex (including facies $a-e$ ) facies $a$ represents a near-shore lagoonal sand, characterised by fine sand rich in detritus and terrigenous plant remains together with ammonites and various trace fossils of marine origin. Facies $b$ is regarded as a lagoonal mud, while facies $c$ represents the offshore bar bordering the lagoon towards the ocean. The occurrence of the characteristic Stenocraterion 'pipe rock' supports this. Facies $d$ represents the transition between deposition above wave base at a sand bar, and the deposition of offshore muds of facies $e$ below the wave base. The trace fossils of facies $d$ (Teichichnus) and of facies $e$ (Zoophycos) are in accordance with this change to more open marine conditions, as is the occurrence of the fairly diverse ammonite fauna in facies $e$.

The upper unit comprises the remaining facies $f$ and $g$. Facies $f$ is typical of the coastal sand deposited in a high energy environment, while facies $g$ comprises shelf mud with occasional storm sand layers. The gradual increase in sand upwards, probably reflects a general shallowing of the basin.

\section{Late Cretaceous}

The Wandel Sea Basin includes thick sequences of Late Cretaceous marine sediments, outcropping at Kilen as well as Nakkehoved (see below) in northern Kronprins Christian Land, and north-east of Frigg Fjord in northern Peary Land (see below). This is in contrast to the situation in other parts of the North Atlantic region. Late Cretaceous sediments have 
so far not been reported from either Svalbard or the Norwegian offshore regions, and are almost unknown in eastern Greenland north of latitude $74^{\circ} \mathrm{N}$.

The sequence at Kilen totals at least $550 \mathrm{~m}$, and is composed of a variety of lithologies including shales, siltstones, sandstones, and intraformational conglomerates (fig. 20). The lower $350 \mathrm{~m}$ are characterised by an apparently unsystematic change between silty shales, heterolithic sand/siltstones, sandstones, and gravel conglomerates with a high content of fragmented inoceramid shells. Sideritic horizons occur throughout the series, either as continuous beds or as scattered, often fairly large, concretions.

Fossils are abundant, particularly in association with the concretions. A few species of scaphitid ammonites and inoceramid bivalves constitute the entire fauna. Preliminary investigation of the fauna indicates the sequence to be of Turonian-Coniacian age (E. Kauffman, personal communication).

The upper $200 \mathrm{~m}$ of the sequence is dominated by fine-grained sandstones with at the base some four metres of interbedded mud crack conglomerates. Fossils are less frequent than in the strata below, but include ammonites, belemnites, and inoceramids as well as plant fragments. Indistinct burrow structures are frequent, and a few distinct types were noted (Stenocraterion, Phoibichnus, and Rhizocorallium).

The Late Cretaceous sequence of Kilen apparently represents a single, regressive event with offshore marine silts and sands below, and relatively near-shore sands above.

\section{Kap Rigsdagen: Early Cretaceous}

Approximately $85 \mathrm{~m}$ of clastic sediments are exposed south of Kap Rigsdagen in Valdemar Glückstadt Land. The sediments, generally, fine upwards with the lower $40 \mathrm{~m}$ of coarse sandstone and gravelstone giving way to shaly siltstones and mudstones at the top. The coarse sandstone at the base shows well-developed, mainly planar, cross-bedding with a general direction of transport towards the east. In the central part of the sequence a mixture of trough cross-bedded, coarse sandstones and silty shales dominate, while the upper $30 \mathrm{~m}$ comprise medium-grained sandstones, siltstones and, at the very top, shaly mudstone. In the sandstones, various types of large and small scale cross-bedding as well as lenticular bedding were noted.

Very thin coal seams and carbonized plant remains, together with root horizons, occur in the middle part of the sequence. Low diversity assemblages of dinoflagellate cysts indicate an Aptian age for most of the sequence (S. Piasecki, personal communication).

The upper part of the sequence probably represents a restricted marine to lagoonal environment, while the lower sandy part may possibly be interpreted as the foreshore/shoreface deposits of a longshore protective bar system. What may be considered an open marine equivalent to this coastal facies was located this summer in eastern Peary Land (Rolle, this report).

\section{Nakkehoved Formation}

The Nakkehoved Formation (Håkansson, 1979) comprises approximately $600 \mathrm{~m}$ of very monotonous, fine-grained greywackes exposed in a number of nunataks and semi-nunataks along the north coast of Kronprins Christian Land. The sequence is, in general, very gently 
disturbed and neither the lower, nor the upper boundary has been found exposed. In Erik S. Henius Land and at Nordostrundingen the low fringe of land is almost exclusively composed of material derived from the Nakkehoved Formation sandstones, but no exposures were located.

The sparse fauna of bivalves, listed from the Nakkehoved Formation (Nielsen, 1941; Håkansson, 1979), were found to be somewhat richer than previously known. Apart from nuculoid and posidonioid bivalves, additional species of heterodont and trigoniid bivalves were collected which may refine the Late Cretaceous age determination.

The bivalves, as well as thin burrow tubes, are preserved virtually undistorted, with open voids after dissolved shells. The feldspar grains commonly have well developed, neomorphic mica envelopes, and their internal parts have often been partly transformed into epidote. In conjunction with these observations, a number of closely spaced, approximately $\mathrm{N}-\mathrm{S}$ trending quartz veins were found in one of the nunataks. The veins were probably formed at temperatures of $214^{\circ} \mathrm{C}$ (or slightly above) at shallow depth which, together with the prevailing state of fossil preservation, indicates that the low grade metamorphism had an exclusively thermal origin (unpublished manuscript, E. Håkansson, J. Konnerup-Madsen \& S. Piasecki).

\section{Thyra $\emptyset$ Formation}

\section{Cainozoic strata}

The areal extent of the probably Paleocene Thyra $\varnothing$ Formation (Håkansson, 1979) includes the islands Prinsesse Thyra $\varnothing$, Prinsesse Dagmar $\varnothing$, and Prinsesse Margrethe $\varnothing$ as well as the southern half of Prinsesse Ingeborg Halvø with altitudes consistently below 100 $\mathrm{m}$. The degree of exposure is very poor, and in most of the area the Thyra $\varnothing$ Formation is extensively covered by pinkish, marine Quaternary silts commonly overlain by sparse glacial erratics. The sequence is virtually horizontal with no dips in excess of $8^{\circ}$. The base of the Thyra $\emptyset$ Formation has never been observed, and the top has been removed by Quaternary erosion.

The Thyra $\varnothing$ Formation is dominated by fine-grained, silty to sandy shales with subordinate occurrences of coarser sandstone and coal seams. Finely disseminated carbonaceous detritus is typically present. Although exposures are few and no single section comprises more than $50 \mathrm{~m}$, some regional differentiation in facies is evident.

All sequences investigated on Prinsesse Thyra $\emptyset$, as well as the very poor exposures on Prinsesse Dagmar $\varnothing$, comprise the same facies types recorded by Håkansson (1979), varying only in relative importance. The strata exposed on the southern half of Prinsesse Ingeborg Halvø deviate somewhat from this pattern by having much less carbonaceous matter in the clastic sediments. On the other hand, the actual coal beds in this area are of considerable thickness, reaching, locally, as much as $2 \mathrm{~m}$.

On Prinsesse Margrethe $\varnothing$ the single, isolated outcrop exhibits approximately $15 \mathrm{~m}$ of coarse conglomerate unknown in any other part of the sequence. The conglomerate is dominated by poorly rounded to subangular blocks which reach more than $50 \mathrm{~cm}$ in size. No block orientation is apparent, and in general the conglomerate is block-supported with faint indication of cross stratification. Interbedded lenticular channel fills are dominated by fineto medium-grained sandstone in trough cross beds with single sets exceeding $25 \mathrm{~cm}$. The sandstone, in particular, contains abundant, finely dispersed carbonaceous material. 
However, no direct evidence is available to correlate the sequence of the latter area with the Thyra Ø Formation. Determinable organic walled microfossils are highly sporadic as a result of subsequent thermal influence (S. Piasecki, personal communication), and the assemblage of leaves, so characteristic of the type region, has so far been found only on Prinsesse Dagmar Ø and, more rarely, in the southern half of Prinsesse Ingeborg Halvø. The conglomerate on Prinsesse Margrethe $\emptyset$ is considered a proximal equivalent to the finegrained, fluvial sediments which dominate the formation.

The depositional environment of the Thyra Ø Formation is fluvial, although some marine influence is suggested by rare dinoflagellates in some levels (Croxton, in Håkansson, 1979). For the majority of the sequence, deposition in a near-shore fluvial plain setting is most likely, probably associated with proximal alluvial fan conglomerates towards the east.

\section{Tectonics of northern Kronprins Christian Land}

In northern Kronprins Christian Land sediments of the Wandel Sea Basin were variously disturbed subsequent to the formation of the Caledonian nappe complex. Some pattern may be deduced from the following list of structural observations.

(1) Permo-Carboniferous rocks in northern Prinsesse Ingeborg Halvø are strongly folded with associated, local, low grade metamorphism (constructed axis of the $F_{2}$ phase is $330 / 30^{\circ}$ - see earlier section on the basement).

(2) Early Permian rocks in northern Amdrup Land are very weakly folded (axes trend approximately $\mathrm{E}-\mathrm{W}$ ).

(3) Late Jurassic to Valanginian (and younger?) rocks of Kilen are folded in distinct, en echelon domes (longitudinal axes between 75 and $115^{\circ}$ ).

(4) Late Cretaceous rocks in the Nakkehoved region are very weakly folded (axes not determined).

(5) Turonian-Coniacian rocks of Kilen are folded in distinct, en echelon domes (longitudinal axes trend on average at $100^{\circ}$ ).

(6) A steep fault, striking approximately $80^{\circ}$, separates Permo-Carboniferous rocks from the Wandel Sea Basin basement in northern Prinsesse Ingeborg Halvø.

(7) A steep fault, striking approximately $110^{\circ}$, separates Valanginian (and younger?) rocks from Turonian-Coniacian rocks in Kilen.

(8) A steep, wide fault zone, striking approximately $150^{\circ}$, separates the folded complex of northern Prinsesse Ingeborg Halvø from the flat-lying, probably Paleocene strata of the Thyra $\emptyset$ Formation to the south.

From these observations it is evident that:

(A) Strong folding, associated with low grade metamorphism, took place in the late Permian to early Paleocene period.

(B) Post-Coniacian folding has been substantial.

(C) Post-Paleocene faulting has been substantial.

Since $\mathrm{A}$ and $\mathrm{C}$ are mutually exclusive, whereas $\mathrm{B}$ in theory may be associated with either of them, at least two tectonic events are required to accommodate these inferences. How- 
ever, the axes of the $F_{2}$ phase in Prinsesse Ingeborg Halvø seem to be close to the range of variation recorded in the axes of the domes in Kilen. On balance, therefore, it may be argued that $\mathrm{A}$ and $\mathrm{B}$ are related and, thus, that the main folding of the $\mathrm{F}_{2}$ phase in northern Kronprins Christian Land is most likely to have taken place within the post-Coniacian to Paleocene period.

In addition to these disturbances a purely thermal metamorphism with associated quartz veins had an influence on the rocks of the Nakkehoved Formation. Since this thermal event has also influenced the Paleocene sediments of the Thyra $\varnothing$ Formation it is most likely related to the post-Paleocene faulting phase (unpublished manuscript, E. H., J.K-M. \& S.P. - see earlier).

The fact that preservation of palynomorphs varies distinctly in different parts of Kilen in spite of the uniform deformation, further substantiates the difference between the deformation phase and the subsequent thermal phase mentioned above.

\section{Harder Fjord fault zone}

The Harder Fjord fault zone is an up to $5 \mathrm{~km}$ wide, E-W trending system of faults which can be traced for more than $200 \mathrm{~km}$ through the southern part of the North Greenland fold belt (Pedersen, 1980; Higgins et al., this report). The fault zone is dominated by Frigg Fjord mudstone around Frigg Fjord, and in addition to abundant greenstones several outcrops of younger sedimentary units have been reported (Soper et al., 1980; Croxton et al., 1980). In 1980 a number of localities in the fault zone between Depotbugt in the east and Columbus Sø in the west were visited. Poor exposure in the fault zone makes it difficult to establish individual fault-bounded units, but it appears that no strata from the Wandel Sea Basin sequence have been down-faulted in the Harder Fjord fault zone west of Frigg Fjord, and that the fault-bounded units east of Depotbugt are considerably larger than in southern Johannes V. Jensen Land.

\section{Depotbugt}

At Depotbugt a sequence comprising more than $500 \mathrm{~m}$ of conglomerates, poorly sorted sandstones, greywackes and siltstones are preserved.

The lower part of the sequence is dominated by pebbly to cobbly conglomerates, commonly inpregnated with siderite(?). These units vary from clast-supported to matrix-supported conglomerates and sparse conglomeratic sandstones with well rounded clasts. Cyclic changes between heterolithic siltstone/sandstone and intervals of non-heterolithic siltstone are recorded through most of the sequence. Trough cross-bedded sandstone is common, and some levels are characterised by large, internal scours. Carbonaceous material is abundant, and locally abundant stem impressions (A. K. Higgins, personal communication) as well as a single impression of a conifer twig were found.

The sequence dips fairly uniformly towards the south, where it disappears beneath the cover of the valley floor. Towards the north the contact with the folded rocks of the Paradisfjeld Group is a fault which forms a prominent lineament (Soper et al., 1980; Croxton et al., 1980), occasionally obscured by dykes. The fault is considered to be reverse and dips towards the south at a somewhat steeper angle than the sediment sequence above.

No age diagnostic fossils have been found in this sequence. Judging from the dominant 
lithologies, we suggest that it is referred to the lower part of the Herlufsholm Strand Formation in east Peary Land (Håkansson, 1979) in which palynomorphs have similarly been lost during diagenesis (S. Piasecki, personal communication). The age of the Herlufsholm Strand Formation is vaguely determined as late Cretaceous - early Tertiary by Troelsen (1950).

A very restricted palynomorph assemblage points to a probably Tertiary age of some shales from the central part of the Harder Fjord fault zone immediately east of Depotbugt (Croxton et al., 1980). Little is known about the field relations of these shales, and their relation to the sequence described above is totally obscured by the valley floor cover. However, the palynomorph assemblage described by Croxton et al. (1980) is significantly less degraded than the organic constituents of the sequence described here (S. Piasecki, personal communication) and, most likely, this difference is directly related to differences in the diagnetic histories. It is therefore possible that the two sedimentary suites are separated in time by a significant deformational event.

\section{Midtkap}

A small, fault-bounded lens of strongly deformed sediments was located in the low coastal hills NNE of Midtkap. The sequence comprises greywacke sandstones, conglomerates, and silty to coaly shales with abundant impressions of late Palaeozoic plants. Undoubtedly, this small occurrence of fluvial or deltaic sediments is closely related to the nearby sequence of similar sediments of Late Permian age (Soper et al., 1980; Wagner et al., in press). This additional occurrence of the limnic Permian is surrounded entirely by Frigg Fjord mudstones and is not associated with the greenstones mentioned by Soper $e t$ al. (1980).

\section{North-east of Frigg Fjord}

During the field work in 1979, J. D. Friderichsen located a sequence of Cretaceous sediments in the Harder Fjord fault zone east of Grønnemarken (Soper et al., 1980). This summer's field work established the presence of a sequence of more than $400 \mathrm{~m}$ of Cretaceous strata.

The Cretaceous sequence is terminated upwards (i.e. towards the north) by an almost vertical fault against strongly folded slates, which are probably referable to the formations A and B (S. S. Pedersen, personal communication), overlain by Silurian(?) turbidites. In the small exposure the fault is roughly parallel to bedding in both units, and both young towards the fault plane.

The Cretaceous sequence is dominated by fairly homogeneous, fine-grained sandstones and indistinctly laminated siltstones. The lower part is mainly light brown weathering, finegrained sandstones; the middle part is dominated by almost black weathering siltstones which, due to a weak cleavage, are commonly shard-like; the upper part is dominated by light grey weathering, very fine-grained sandstones with a few, thin conglomeratic beds.

Trace fossils have been noted sparsely throughout the sandstone intervals, whereas body fossils were found only in the siltstones. However, loose finds indicate that this fauna also occurs in the lower, brown weathering sandstone. The fauna consists of a number of protobranch bivalves from a single level in addition to more widespread inoceramids. In most cases the inoceramids, commonly associated with sideritic concretions in the siltstones, are crushed more or less in situ, but, sporadically, have almost preserved their original shape. 
Some specimens may reach more than $50 \mathrm{~cm}$ in length. From this fauna Sphenoceramus pinniformis (Willet) has been identified (E. Kauffman, personal communication), indicating a Late Santonian age for at least the central part of the sequence. So far no determinable palynomorphs have been found (S. Piasecki, personal communication).

\section{Kap Cannon thrust zone}

During reconnaissance investigations in 1979 a Late Palaeozoic sequence was located in close association with strata from the Cretaceous Kap Washington Group in the Kap Cannon thrust zone in the northernmost exposed part of the North Greenland fold belt (Soper et al., 1980). Continued field work by several parties this summer (see elsewhere in this report) has elucidated many of the problems arising from this and subsequent unexpected occurrences of sediments referable to the Wandel Sea Basin.

\section{Lockwood $\emptyset$ and Kap Kane}

At the northwestern part of Lockwood $\varnothing$ a sequence of more than $600 \mathrm{~m}$ rests with an angular unconformity on isoclinally folded, green and purple phyllites, possibly of Frigg Fjord mudstone. The basal late Palaeozoic red beds comprise at least $45 \mathrm{~m}$ of coarse conglomerates and sandstones with subordinate siltstone beds. The remaining sediments in the sequence are dominated by light chert or cherty limestones and dark shales. In places the limestones contain rich faunas of stenoporid and fenestrate bryozoans as well as productid and spiriferid brachiopods which indicate a Late Carboniferous - Permian age for the sequence.

The Permo-Carboniferous sequence dips fairly uniformly to the south-east and is separated from apparently overlying sediments from the base of the Kap Washington Group by a reverse fault largely parallel to bedding. These Kap Washington Group sediments, mainly sandstones, are Cretaceous in age (Batten et al., 1981). Along the west coast of Lockwood $\varnothing$ the Permo-Carboniferous sequence wedges out between this reverse fault and an additional, less steep thrust plane. As a probable result of the thrust movement, a faint cleavage is developed in the shaly portions, and the brachiopods are commonly plastically distorted.

Irregular, slightly discordant dolerite sheets are abundant and amount to more than one third of the measured sequence, with individual sheets reaching at least $100 \mathrm{~m}$ in thickness. The intrusions appear to be mainly basaltic with epidotized slickensides indicating later alteration.

A largely similar sequence dominated by dark shales and bounded by faults, was briefly visited south of Kap Kane. 


\section{References}

Batten, D.J., Brown, P. E., Dawes P. R., Higgins, A. K., Koch, B. E., Parsons, I. \& Soper, N. J. 1981: Peralkaline volcanicity on the Eurasia Basin margin. Nature 294, 150-152.

Bendix-Almgreen, S. E. 1975: Fossil fishes from the Marine Late Palaeozoic of Holm Land - Amdrup Land, North-East Greenland. Meddr Grønland 195(9), $38 \mathrm{pp.}$

Croxton, C. A., Dawes, P. R., Soper, N. J. \& Thomsen, E. 1980: An occurrence of Tertiary shales from the Harder Fjord Fault, North Greenland fold belt, Peary Land. Rapp. Grønlands geol. Unders. 101, $61-64$

Cutbill, J. L. \& Challinor, A. 1965: Revision of the stratigraphical scheme for the Carboniferous and Permian of Spitsbergen and Bjørnøya. Geol. Mag. 102, 418-439.

Dawes, P. 1976: Precambrian to Tertiary of northern Greenland. In Escher, A. \& Watt, W. S. (edit.) Geology of Greenland, 249-303. Copenhagen: Geol. Surv. Greenland.

Douglass, R. C. 1977: Development of fusulinid biostratigraphy. In Kaufmann, E. G. \& Hazel, J. E. (edit.) Concepts and methods of biostratigraphy, 463-481. Dowden, Hutchinson \& Ross, Stroudsburg, Pennsylvania.

Dunbar, C. E., Troelsen. J., Ross, C., Ross, J. P. \& Norford, B. 1962: Faunas and correlation of the late Paleozoic rocks of Northeast Greenland. Part 1. General discussion and summary. Meddr Grønland 167(4), 16 pp.

Flood, B., Nagy, J. \& Winsnes, T. S. 1971: Geological map Svalbard 1: 500.000. Sheet 1G Spitsbergen, Southern part. Skr. Norsk Polarinst.

Frebold, H. 1950: Stratigraphie und Brachiopodenfauna des Marinen Jungpalaeozoikums von Holms Land und Amdrups Land (Nordostgrönland). Meddr Grønland 126(3), 97 pp.

Grönwall, K. G. 1916: The marine Carboniferous of North-East Greenland and its brachiopod fauna. Meddr Grønland 43(20), 110 pp.

Håkansson, E. 1979: Carboniferous to Tertiary development of the Wandel Sea Basin, eastern North Greenland. Rapp. Grønlands geol. Unders. 88, 73-83.

Håkansson, E., Birkelund, T., Piasecki, S. \& Zakharov, V. 1981: Jurassic - Cretaceous boundary strata of the extreme arctic (Peary Land, North Greenland). Bull. geol. Soc. Denmark 30, 11-42.

Håkansson, E. \& Heinberg, C. 1977: Reconnaissance work in the Triassic of the Wandel Sea Basin, Peary Land, eastern North Greenland. Rapp. Grønlands geol. Unders. 85, 11-15.

Koch, L. 1929: Stratigraphy of Greenland. Meddr Grønland 73(2), 116 pp.

Nathorst, A. G. 1911: Contributions to the Carboniferous flora of Northeastern Greenland. Meddr Grønland 43(12), $10 \mathrm{pp}$.

Nielsen, E. 1941: Remarks on the map and geology of Kronprins Christians Land. Meddr Grønland 126(2), 34 pp.

Pedersen, S. A. S. 1980: Regional geology and thrust fault tectonics in the southern part of the North Greenland fold belt, north Peary Land. Rapp. Grønlands geol. Unders. 99, 79-87.

Soper, J., Higgins, A. K. \& Friderichsen, J. D. 1980: The North Greenland fold belt in eastern Johannes V. Jensen Land. Rapp. Grønlands geol. Unders. 99, 89-98.

Troelsen, J. 1950: Geology In Winther, P. C. et al. A preliminary account of the Danish Pearyland Expedition, 1948-9. Arctic 3, 6-8.

Wagner, R. H., Soper, N. J. \& Higgins, A. K. in press: A Late Permian flora of Pechora affinity in North Greenland. Rapp. Grønlands geol. Unders.

Worsley, D. \& Mørk, A. 1980: Excursion guide to Isfjorden, Svalbard. 50 pp. Tronheim: Continental Shelf Institute. 